\title{
Hydrogenophilus islandicus sp. nov., a thermophilic hydrogen-oxidizing bacterium isolated from an Icelandic hot spring
}

\author{
Hildur Vésteinsdóttir, Dagný B. Reynisdóttir and Jóhann Örlygsson \\ Faculty of Natural Resource Science, University of Akureyri, Borgir v. Nordurslod, 600 Akureyri, \\ Iceland
}

Correspondence

Johann Orlygsson

jorlygs@unak.is

\begin{abstract}
A novel chemolithotrophic bacterium, strain $16 \mathrm{C}^{\top}$, was isolated from a hot spring in Graendalur, south-west Iceland. Cells of this organism were Gram-negative, rod-shaped and motile. The isolate was aerobic and capable of chemolithotrophic growth on hydrogen and carbon dioxide, heterotrophic growth on butyrate and several other organic compounds, and mixotrophic growth on butyrate, hydrogen and carbon dioxide. Heterotrophic growth was generally enhanced in the presence of yeast extract. Autotrophic growth on hydrogen was observed at $\mathrm{pH}$ values between 6.0 and 10.0 and temperatures between 35 and $60{ }^{\circ} \mathrm{C}$; optimum growth conditions were $\mathrm{pH} 7.0$ and $55^{\circ} \mathrm{C}$. The DNA G $+\mathrm{C}$ content was $63.9 \mathrm{~mol} \%$. 16S rRNA gene sequence analysis showed that strain $16 \mathrm{C}^{\top}$ was a member of a distinct species belonging to the class Betaproteobacteria and was most closely related to Hydrogenophilus thermoluteolus NBRC $14978^{\top}$ and Hydrogenophilus hirschii DSM $11420^{\top}$. The major cellular fatty acids were straight-chain $\mathrm{C}_{16: 0}$ $(44.98 \%)$ and $\mathrm{C}_{18: 1} \omega 7 c(17.93 \%)$, as well as cyclic $\mathrm{C}_{17: 0}(13.90 \%)$ and $\mathrm{C}_{19: 0} \omega 8 \mathrm{c}(4.67 \%)$ fatty acids. Based on its physiological and molecular properties, it is concluded that strain $16 \mathrm{C}^{\top}$ represents a novel species within the genus Hydrogenophilus, for which the name Hydrogenophilus islandicus is proposed; the type strain is $16 \mathrm{C}^{\top}\left(=\mathrm{DSM} 21442^{\top}=\mathrm{JCM} 16106^{\top}\right)$.
\end{abstract}

Members of the genus Hydrogenophilus were first studied by Goto and co-workers (Goto et al., 1977, 1978). They isolated strains that were assigned to two different genera, Pseudomonas and Flavobacterium (Goto et al., 1977, 1978). These strains have now been reassigned to the genus Hydrogenophilus based on further phylogenetic studies (Hayashi et al., 1999). Members of the genus Hydrogenophilus are straight rods, Gram-negative, nonsporulating and use the Calvin cycle to fix carbon dioxide (Aragno \& Schlegel, 1992). The genus comprises two moderately thermophilic species isolated from geothermal areas, Hydrogenophilus thermoluteolus (type strain NBRC $14978^{\mathrm{T}}$ ), isolated from a geothermal site in Japan (Goto et al., 1977; Hayashi et al., 1999), and Hydrogenophilus hirschii (type strain DSM $11420^{\mathrm{T}}$ ), isolated from Yellowstone National Park, USA (Stöhr et al., 2001).

In this study, a novel hydrogen-oxidizing (HOX) bacterium is described that was isolated from a hot spring in Graendalur, south-west Iceland.

Abbreviations: HOX, hydrogen-oxidizing; SEM, scanning electron microscopy; SOX, sulfur-oxidizing.

The GenBank/EMBL/DDBJ accession number for the 16S rRNA gene sequence of strain $16 C^{\top}$ EU625664.

A supplementary figure and supplementary table are available with the online version of this paper.
Samples of liquid and mud collected from an off flow of a hot spring $\left(54{ }^{\circ} \mathrm{C}, \mathrm{pH} 6.75\right)$ were inoculated $[10 \%(\mathrm{v} / \mathrm{v})]$ into DSMZ medium 81, a mineral medium for chemolithotrophic growth (DSMZ, 2006), containing $0.1 \mathrm{mg}$ resazurin $1^{-1}$. The bottles contained atmospheric air, but were pressurized with $101 \mathrm{kPa}(1 \mathrm{~atm})$ of a filter-sterilized hydrogen and carbon dioxide mixture $(80: 20, \mathrm{v} / \mathrm{v})$ resulting in final gas phase of $202 \mathrm{kPa}$ (2 atm) consisting of $\mathrm{H}_{2} / \mathrm{CO}_{2} / \mathrm{N}_{2} / \mathrm{O}_{2}$ (40:10:40:10, by vol.). Strain $16 \mathrm{C}^{\mathrm{T}}$ was isolated using repeated enrichments $[10 \%(\mathrm{v} / \mathrm{v})$ inoculation] and end-point dilution series. A pure culture of strain $16 \mathrm{C}^{\mathrm{T}}$ was obtained by inoculating solid media on agar plates from the final positive bottle of the dilution series. DSMZ medium 81 was solidified by the addition of agar $\left(15 \mathrm{~g} \mathrm{l}^{-1}\right)$. After sterilization, the medium was poured into agar plates, which were inoculated in an airtight jar containing the same gas composition as before. Three greyish, round colonies, approximately $1 \mathrm{~mm}$ in diameter, were reinoculated into liquid medium and analysed for $16 \mathrm{~S}$ rRNA. The three colonies showed $100 \%$ sequence similarity with each other based on $16 \mathrm{~S}$ rRNA analysis performed as described below. Examination of culture purity and morphology was conducted using standard phase-contrast microscopy and scanning electron microscopy (SEM). For SEM, cells were fixed with $2 \%$ glutaraldehyde and dried in ethanol prior to critical-point 
drying. Before examination by SEM, the sample was coated with gold. Gram-staining was assayed as described by Smibert \& Krieg (1994) and motility was tested by growth in liquid medium (DSMZ medium 81) under heterotrophic conditions on butyrate and confirmed microscopically by motility in a hanging-drop preparation. SEM revealed that cells of strain $16 \mathrm{C}^{\mathrm{T}}$ were Gram-negative, straight rods, $2.6 \mu \mathrm{m}$ long and $0.4 \mu \mathrm{m}$ wide, occurring as single cells (see Supplementary Fig. S1 available in IJSEM Online).

Growth characteristics were determined from optical density $\left(\mathrm{OD}_{600}\right)$ data. All experiments were conducted in duplicate. Experiments to determine the optimum $\mathrm{pH}$ and temperature for growth were performed using the same medium (DSMZ medium 81) under heterotrophic conditions with $20 \mathrm{mM}$ butyrate. For determination of optimum growth temperature, the isolate was grown at $\mathrm{pH} 6.8$ and $20-75{ }^{\circ} \mathrm{C}$. For determination of optimum growth $\mathrm{pH}$, the isolate was grown at $50{ }^{\circ} \mathrm{C}$ and the initial $\mathrm{pH}$ (measured at room temperature) was adjusted over the range $\mathrm{pH} 3.0$ to $\mathrm{pH}$ 10.0. The isolate grew between 35 and $60{ }^{\circ} \mathrm{C}$, with optimum growth at $55{ }^{\circ} \mathrm{C}$. No growth was observed at $30{ }^{\circ} \mathrm{C}$ or below or at $65{ }^{\circ} \mathrm{C}$ or above. Optimum pH was 7.0, but the strain was able to grow at $\mathrm{pH}$ 6.0-10.0.

The ability of strain $16 \mathrm{C}^{\mathrm{T}}$ to utilize various organic substrates under heterotrophic conditions was tested under aerobic conditions at $50{ }^{\circ} \mathrm{C}$ using liquid medium supplemented with various filter-sterilized substrates at a final concentration of $20 \mathrm{mM}$ (or $2 \mathrm{~g} \mathrm{l}^{-1}$ in the case of yeast extract, beef extract, peptone and tryptone). Substrate utilization was tested in the presence and absence of yeast extract $\left(2 \mathrm{~g} \mathrm{l}^{-1}\right)$ over a cultivation period of 5 days. Growth was monitored by measuring the increase in $\mathrm{OD}_{600}$. In the absence of yeast extract, growth was observed on butyrate, beef extract, tryptone, propionate, lactate and pyruvate and weak growth was observed on crotonate and peptone (Table 1). In the presence of yeast extract, growth was enhanced on most of the above-mentioned substrates

Table 1. Characteristics of strain $16 \mathrm{C}^{\top}, H$. hirschii and $H$. thermoluteolus

Strain: 1, 16C ${ }^{\mathrm{T}}$; 2, H. hirschii DSM $11420^{\mathrm{T}}$ (Stöhr et al., 2001); 3, H. thermoluteolus NBRC $14978^{\mathrm{T}}$ (Goto et al., 1978; Hayashi et al., 1999; Miyake et al., 2007). All strains were positive for growth on hydrogen, pyruvate and lactate and negative for growth on formate, xylose, galactose and sucrose. + , Positive; $+^{*}$, positive in the presence of yeast extract; $w$, weakly positive; -, negative; ND, not determined.

\begin{tabular}{|c|c|c|c|}
\hline Characteristic & 1 & 2 & 3 \\
\hline \multicolumn{4}{|l|}{ Heterotrophic growth } \\
\hline Acetate & $+^{*}$ & + & + \\
\hline Alanine & - & - & ND \\
\hline Aspartate & - & $\mathrm{ND}$ & $\mathrm{ND}$ \\
\hline Beef extract & + & + & $\mathrm{ND}$ \\
\hline Butyrate & + & - & + \\
\hline Crotonate & $\mathrm{W}$ & $\mathrm{ND}$ & $\mathrm{ND}$ \\
\hline Fructose & $+^{*}$ & - & - \\
\hline Glucose & $+^{*}$ & - & - \\
\hline Glutamate & - & + & ND \\
\hline Glycine & - & - & $\mathrm{ND}$ \\
\hline Histidine & - & - & $\mathrm{ND}$ \\
\hline$\alpha$-Ketoglutarate & - & - & + \\
\hline Malate & $+^{*}$ & + & + \\
\hline Oxalate & - & $\mathrm{ND}$ & - \\
\hline Peptone & $\mathrm{w}$ & + & $\mathrm{ND}$ \\
\hline Propionate & + & $\mathrm{ND}$ & + \\
\hline Serine & - & $\mathrm{ND}$ & $\mathrm{ND}$ \\
\hline Sorbitol & - & $\mathrm{ND}$ & - \\
\hline Succinate & - & + & + \\
\hline Threonine & - & $\mathrm{ND}$ & $\mathrm{ND}$ \\
\hline Tryptone & + & + & $\mathrm{ND}$ \\
\hline Yeast extract & + & + & $\mathrm{ND}$ \\
\hline \multicolumn{4}{|l|}{ Chemolithotrophic growth } \\
\hline Thiosulfate & - & - & + \\
\hline Optimum growth temperature $\left({ }^{\circ} \mathrm{C}\right)$ & 55 & $60-65$ & $50-52$ \\
\hline Optimum growth $\mathrm{pH}$ & 7.0 & 6.5 & 7.0 \\
\hline DNA $G+C$ content $(\mathrm{mol} \%)$ & 63.9 & 61.0 & $63-65$ \\
\hline Motility & + & + & - \\
\hline
\end{tabular}


and, in addition, growth was observed on fructose, glucose, malate and acetate (no growth occurred on these substrates without yeast extract). No growth was observed on formate, oxalate, aspartate, glutamate, alanine, glycine, serine, threonine, histidine, xylose, mannose, sucrose, galactose or sorbitol. Chemolithotrophic growth occurred on hydrogen, but not thiosulfate (Table 1).

Special growth experiments were done under HOX, sulfuroxidizing (SOX), heterotrophic and mixotrophic conditions. Growth experiments under HOX conditions were performed using DSMZ medium 81 with a final gas phase consisting of $\mathrm{H}_{2} / \mathrm{CO}_{2} / \mathrm{N}_{2} / \mathrm{O}_{2} \quad(40: 10: 40: 10$, by vol.). Hydrogen was analysed according to Orlygsson \& Baldursson (2007). During growth under HOX conditions, the hydrogen oxidation rate was $0.49 \mathrm{mmol} \mathrm{H}_{2} \mathrm{l}^{-1} \mathrm{~h}^{-1}$ and hydrogen concentration dropped from 24.8 to $2.9 \mathrm{mmol} \mathrm{l}^{-1}$. The doubling time was $10.1 \mathrm{~h}$ with maximum $\mathrm{OD}_{600}$ of 1.1 (Fig. 1a).

Growth was also tested under SOX conditions at $50{ }^{\circ} \mathrm{C}$ using DSMZ medium 81 supplemented with thiosulfate $(40 \mathrm{mM})$ and a gas phase consisting of $\mathrm{N}_{2} / \mathrm{CO}_{2} / \mathrm{O}_{2}$

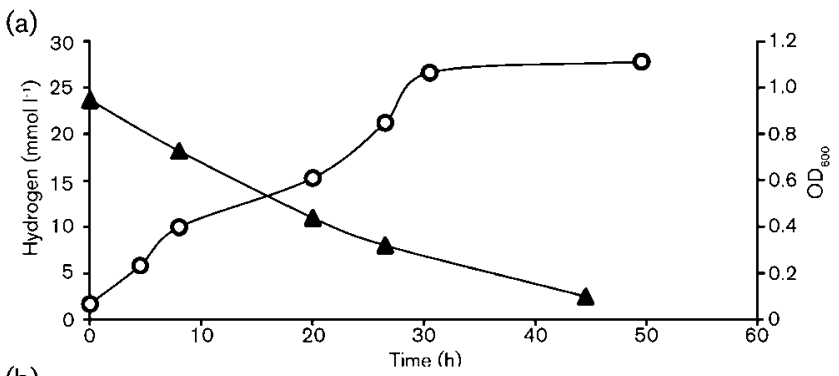

(b)

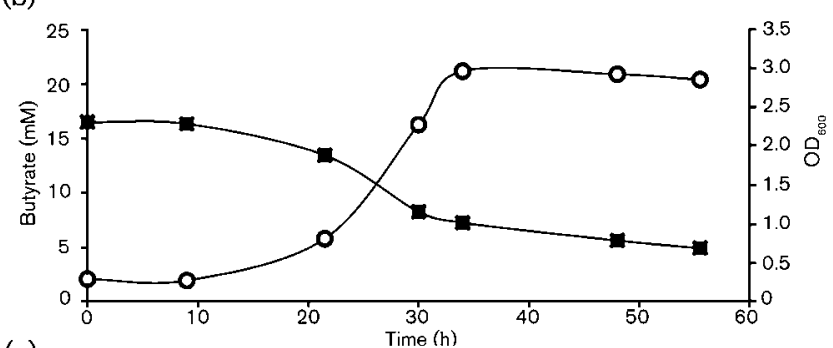

(c)

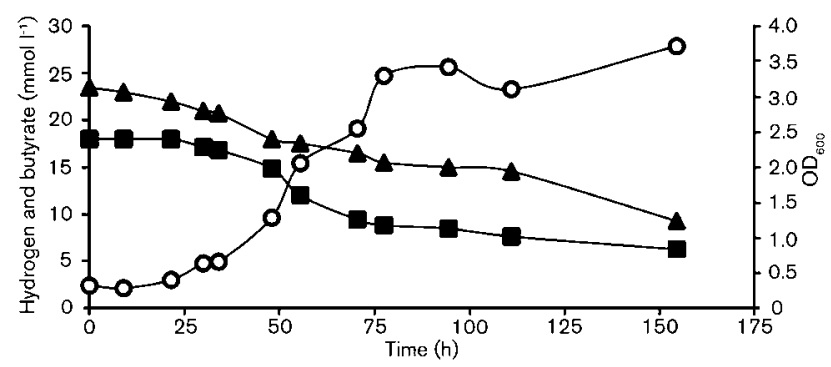

Fig. 1. Growth of strain $16 C^{\top}$ under various growth conditions: (a) HOX conditions; (b) heterotrophic conditions on butyrate; (c) mixotrophic conditions on hydrogen and butyrate. $\boldsymbol{\Delta}$, Hydrogen concentration; $\bigcirc$, growth; $\mathbf{\square}$, butyrate concentration.
$(60: 20: 20$, by vol.). The strain was not able to utilize thiosulfate.

Growth experiments under heterotrophic conditions were performed in atmospheric air using butyrate as substrate. Butyrate consumption was analysed by GC according to Orlygsson \& Baldursson (2007). Growth was followed by an increase in $\mathrm{OD}_{600}$ resulting in a doubling time of $6.6 \mathrm{~h}$ and butyrate degradation rate of $0.37 \mathrm{mM} \mathrm{h}^{-1}$. Maximum $\mathrm{OD}_{600}$ was 2.9 (Fig. 1b).

Growth experiments under mixotrophic conditions were performed as under HOX conditions with addition of butyrate $(20 \mathrm{mM})$ as carbon source. Hydrogen and butyrate were taken up at a rate of $0.15 \mathrm{mmol} \mathrm{l}^{-1} \mathrm{~h}^{-1}$ and $0.18 \mathrm{mM} \mathrm{h}^{-1}$, respectively. The doubling time under mixotrophic conditions was slower compared with chemolithotrophic and heterotrophic conditions, i.e. $18.2 \mathrm{~h}$ with maximum $\mathrm{OD}_{600}$ of 3.4 (Fig. 1c).

Relatively few data have been reported on hydrogen uptake rates of bacteria within the class Betaproteobacteria. In the few experiments that have been conducted, very different culture conditions have been used and results are thus not comparable with the data from the present study. However, in previous studies in our laboratory, data on hydrogen uptake rates of $H$. hirschii DSM $11420^{\mathrm{T}}$, Cupriavidus necator DSM 428, Hydrogenobacter hydrogenophilus DSM $2913^{\mathrm{T}}$ and Sulfurihydrogenibium azorense DSM $15241^{\mathrm{T}}$ have been performed under the same culture conditions as in the present study. The hydrogen uptake rates of these species varied from $0.18 \mathrm{mmol}^{-1} \mathrm{~h}^{-1}$ (S. azorense DSM $15241^{\mathrm{T}}$ ) to $0.28 \mathrm{mmol}^{-1} \mathrm{~h}^{-1}$ (H. hirschii DSM $11420^{\mathrm{T}}$ ), which were considerably lower than that of strain $16 \mathrm{C}^{\mathrm{T}}$ $\left(0.49 \mathrm{mmol} \mathrm{l}^{-1} \mathrm{~h}^{-1}\right)$. The hydrogen concentration dropped from 23.7 to $4.7 \mathrm{mmol}^{-1}$ during batch growth. The most reasonable explanation for the strain not to completely oxidize the hydrogen is a depletion of oxygen in the culture bottles, which was observed visually by the resazurin indicator. The same applied for mixotrophic growth on hydrogen and butyrate, where the hydrogen oxidation rate was $0.15 \mathrm{mmol} \mathrm{H} \mathrm{l}^{-1} \mathrm{~h}^{-1}$, with hydrogen concentration dropping from 23.5 to $9.3 \mathrm{mmol} \mathrm{l}^{-1}$. The highest $\mathrm{OD}_{600}$ value was obtained under mixotrophic conditions, but the fastest doubling time $(6.6 \mathrm{~h})$ was observed during heterotrophic growth on butyrate. This is consistent with other members of the betaproteobacteria that are facultative autotrophs, which grow better on organic substrates than autotrophically (Aragno \& Schlegel, 1992).

For 16S rRNA analysis, 16S rRNA genes were amplified from DNA by PCR with primers F9 and R1544, which are specific for bacterial genes (Skirnisdottir et al., 2000). PCR products were sequenced with universal $16 \mathrm{~S}$ rRNA primers (F9, F515, F1392, R357, F1195 and R1544) using a Big Dye Terminator Cycle Sequencing Ready Reaction kit (Applied Biosystems). Subsequently, DNA was analysed with an Applied Biosystems 3730 DNA Analyzer. The nucleotide sequence was displayed and analysed with SEQUENCER 
(Gene Code Corporation) (Skirnisdottir et al., 2000). Sequences from $16 \mathrm{~S}$ rRNA gene analysis were uploaded to the NCBI database using nucleotide-nucleotide BLAST (BLASTN). The Ribosomal Database Project was also used to obtain sequences of related strains. The most similar sequences obtained from the databases were aligned with results from sequencing with the BioEdit (Hall, 1999) and CLUSTAL_X (Thompson et al., 1997) programs and final alignments were performed to generate phylogenetic trees using the TREECON program (Van de Peer \& De Wachter, 1997); this was also used to view the trees. Diverse groups of proteobacteria were used as reference species and Pseudomonas aeruginosa ATCC $10145^{\mathrm{T}}$ was used as an outgroup. Results from 16S rRNA analysis of the 1492 bases of strain $16 \mathrm{C}^{\mathrm{T}}$ showed that the strain belonged to the class Betaproteobacteria and was most closely related to $H$. thermoluteolus NBRC $14978^{\mathrm{T}}(96.6 \%)$ and H. hirschii DSM $11420^{\mathrm{T}}$ (95.4\%) (Fig. 2). The DNA G +C content was analysed using HPLC according to Mesbah et al. (1989) and was $63.9 \mathrm{~mol} \%$. The isolate could be distinguished clearly from the most related species, $H$. thermoluteolus, and, according to the $97 \%$ limits proposed by Stackebrandt \& Goebel (1994), should be assigned to a novel species.

Analysis of respiratory quinones was carried out by the DSMZ Identification Service and Dr Brian Tindall, DSMZ, Braunschweig, Germany. The major quinone was determined as ubiquinone- 8 , as also observed for both $H$. hirschii and H. thermoluteolus (Hayashi et al., 1999; Stöhr et al., 2001). Fatty acids were analysed by GC by the DSMZ Identification Service. Straight-chain $\mathrm{C}_{16: 0}(44.98 \%)$ and $\mathrm{C}_{18: 1} \omega 7 c(17.93 \%)$ were the major cellular fatty acid components, but cyclic $\mathrm{C}_{17: 0}(13.90 \%)$ and $\mathrm{C}_{19: 0} \omega 8 \mathrm{c}$
$(4.67 \%)$ were also present in significant amounts (see Supplementary Table S1, available in IJSEM Online). $H$. hirschii has also been found to have a high percentage of straight-chain $\mathrm{C}_{16: 0}$ and the $\mathrm{C}_{17: 0}$ and $\mathrm{C}_{19: 0}$ cyclic fatty acids, but not straight-chain $\mathrm{C}_{18: 0}$ (see Supplementary Table S1 available in IJSEM Online) (Stöhr et al., 2001). Cyclic fatty acids have not been observed in $\mathrm{H}$. thermoluteolus (Hayashi et al., 1999). Thus, there is a clear difference in fatty acid composition between the type strains of $H$. hirschii and $H$. thermoluteolus and strain $16 \mathrm{C}^{\mathrm{T}}$.

Additionally, strain $16 \mathrm{C}^{\mathrm{T}}$ differed from the other two Hydrogenophilus species phenotypically. The temperature optimum for strain $16 \mathrm{C}^{\mathrm{T}}$ was higher $\left(55^{\circ} \mathrm{C}\right)$ than that for H. thermoluteolus $\left(50-52{ }^{\circ} \mathrm{C}\right)$, but the $\mathrm{pH}$ optimum was similar (7.0). H. thermoluteolus has not been reported to grow on complex substrates like peptone, tryptone, meat extract and yeast extract, but grows on simple organic compounds like acetate, propionate, butyrate, succinate, DL-lactate, pyruvate and $\alpha$-ketoglutarate (Hayashi et al., 1999). Strain $16 C^{T}$ grows on complex substrates (peptone, tryptone, meat extract or yeast extract) and many of the organic acids that $H$. thermoluteolus grows on except for succinate and $\alpha$-ketoglutarate. $H$. thermoluteolus utilizes thiosulfate chemolithotrophically (Miyake et al., 2007), but strain $16 \mathrm{C}^{\mathrm{T}}$ does not. Motility can be used to clearly distinguish strain $16 \mathrm{C}^{\mathrm{T}}$ from $H$. thermoluteolus: strain $16 \mathrm{C}^{\mathrm{T}}$ is motile, but $H$. thermoluteolus is not. $H$. hirschii grows on complex substrates such as peptone, tryptone, meat extract and yeast extract (Stöhr et al., 2001) like strain $16 C^{\mathrm{T}}$, but has less capacity to degrade organic acids than strain $16 \mathrm{C}^{\mathrm{T}}$ and $H$. thermoluteolus. Of the three strains, only strain $16 \mathrm{C}^{\mathrm{T}}$ is capable of sugar (glucose, fructose) degradation, although growth is only significant in the presence of yeast

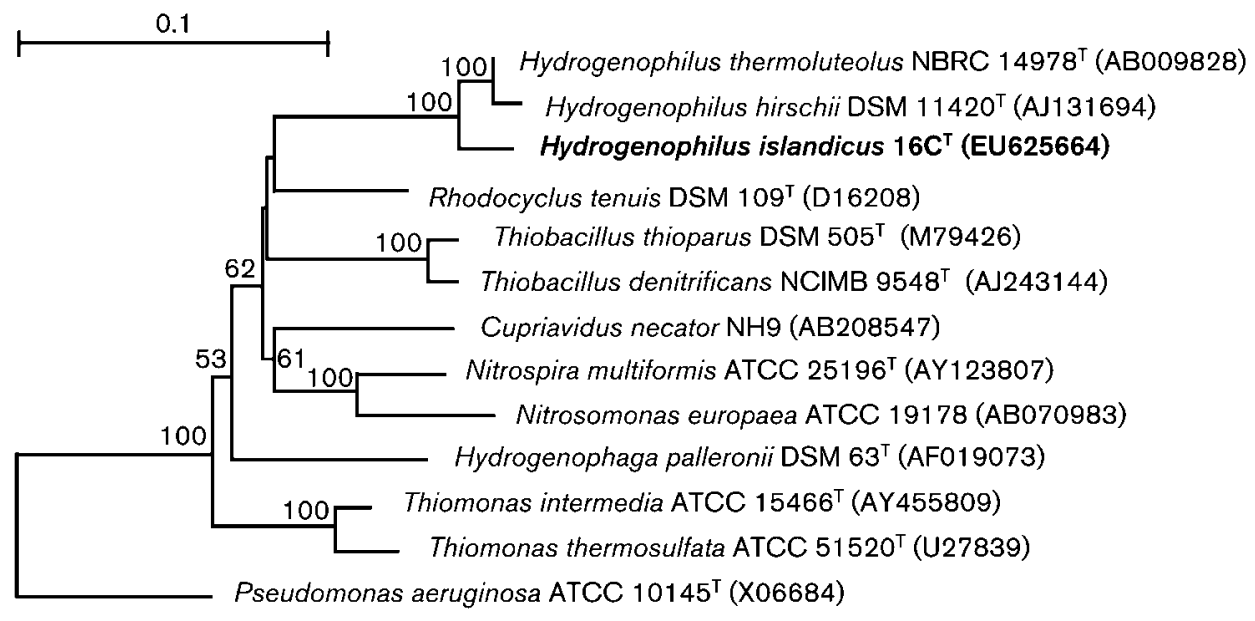

Fig. 2. Phylogenetic tree based on $16 \mathrm{~S}$ rRNA gene sequence comparisons showing the relationship between strain $16 \mathrm{C}^{\top}$ and related type strains. The tree was constructed using the neighbour-joining method, following distance analysis calculated by using the Jukes and Cantor method (Jukes \& Cantor, 1969). Bootstrap values (expressed as percentages of 1000 replications) $>50 \%$ are shown at the branching points. Pseudomonas aeruginosa ATCC $10145^{\top}$ (X06684) was used as the outgroup. Bar, $0.1 \mathrm{nt}$ substitutions per site. 
extract. Additionally, $H$. hirschii has a slightly higher temperature optimum $\left(63{ }^{\circ} \mathrm{C}\right)$ compared with strain $16 \mathrm{C}^{\mathrm{T}}$ and a lower pH optimum (6.5) (Stöhr et al., 2001).

Based on phylogenetic and phenotypic properties, it is proposed that strain $16 \mathrm{C}^{\mathrm{T}}\left(=\right.$ DSM $\left.21442^{\mathrm{T}}=\mathrm{JCM} 16106^{\mathrm{T}}\right)$ represents a novel species in the genus Hydrogenophilus.

\section{Description of Hydrogenophilus islandicus sp. nov.}

Hydrogenophilus islandicus (is.lan.di'cus. N.L. masc. adj. islandicus Icelandic, describing the place of its first isolation).

Cells are Gram-negative, motile, straight rods, $2.6 \mu \mathrm{m}$ long and $0.4 \mu \mathrm{m}$ wide, occurring as single cells or in pairs. Growth occurs under aerobic conditions. Colonies are greyish, round and approximately $1 \mathrm{~mm}$ in diameter. No growth occurs with thiosulfate as the electron donor. Heterotrophic growth is observed on yeast extract, tryptone, beef extract, peptone, propionate, butyrate, lactate, crotonate and pyruvate. In the presence of yeast extract, growth on the majority of substrates is enhanced and, in addition, growth is also observed on fructose, glucose, acetate and malate. No growth is observed on glycine, serine, threonine, alanine, histidine, glutamate, aspartate, oxalate, formate, sorbitol, mannose, xylose, succinate, $\alpha$-ketoglutarate or galactose. Growth factors are not required under chemolithotrophic conditions on hydrogen. The optimum temperature for growth is $55{ }^{\circ} \mathrm{C}$. The maximum temperature is $60{ }^{\circ} \mathrm{C}$ and no growth occurs below $35^{\circ} \mathrm{C}$. The optimum $\mathrm{pH}$ is 7.0 . Doubling times at $50{ }^{\circ} \mathrm{C}$ under $\mathrm{HOX}$ conditions, heterotrophic conditions on butyrate and mixotrophic conditions are 10.1, 6.6 and $18.2 \mathrm{~h}$, respectively.

The type strain is $16 C^{\mathrm{T}}\left(=\mathrm{DSM} 21442^{\mathrm{T}}=\mathrm{JCM} 16106^{\mathrm{T}}\right)$, isolated from a liquid and mud sample taken from a hot spring in Graendalur, south-west Iceland. The DNA G + C content of the type strain is $63.9 \mathrm{~mol} \%$.

\section{Acknowledgements}

This work was sponsored by the Ministry of Industry within the BioTec Net and The Icelandic Research Fund (Rannís) within The Technological Development and Innovation Fund.

\section{References}

Aragno, M. \& Schlegel, H. G. (1992). The mesophilic hydrogenoxidizing (Knallgas) bacteria. In The Prokaryotes, 2nd edn, pp. 344384. Edited by A. Balows, H. Trüper, M. Dworkin, W. Harder \& K.-H. Schleifer. New York: Springer.
DSMZ (2006). Medium 81: Mineral Medium for Chemolithotrophic Growth (H-3). Retrieved October 10, 2006, from Deutsche Sammlung von Mikroorganismen und Zellkulturen GmbH. http://www.dsmz.de/ microorganisms/medium/pdf/DSMZ_Medium81.pdf

Goto, E., Kodama, T. \& Minoda, Y. (1977). Isolation and culture conditions of thermophilic hydrogen bacteria. Agric Biol Chem 41, 685-690.

Goto, E., Kodama, T. \& Minoda, Y. (1978). Growth and taxonomy of thermophilic hydrogen bacteria. Agric Biol Chem 42, 1305-1308.

Hall, T. A. (1999). BioEdit: a user-friendly biological sequence alignment editor and analysis program for Windows 95/98/NT. Nucleic Acids Symp Ser 41, 95-98.

Hayashi, N. R., Ishida, T., Yokota, A., Kodama, T. \& Igarashi, Y. (1999). Hydrogenophilus thermoluteolus gen. nov., sp. nov., a thermophilic, facultatively chemolithoautotrophic, hydrogen-oxidizing bacterium. Int J Syst Bacteriol 49, 783-786.

Jukes, T. H. \& Cantor, C. R. (1969). Evolution of protein molecules. In Mammalian Protein Metabolism, vol. 3, pp. 21-132. Edited by $\mathrm{H}$. N. Munro. New York: Academic Press.

Mesbah, M., Premachandran, U. \& Whitman, W. B. (1989). Precise measurement of the $\mathrm{G}+\mathrm{C}$ content of deoxyribonucleic acid by highperformance liquid chromatography. Int J Syst Bacteriol 39, 159-167.

Miyake, D., Ichiki, S., Tanabe, M., Oda, T., Kuroda, H., Nishihara, H. \& Sambongi, Y. (2007). Thiosulfate oxidation by a moderately thermophilic hydrogen-oxidizing bacterium, Hydrogenophilus thermoluteolus. Arch Microbiol 188, 199-204.

Orlygsson, J. \& Baldursson, S. R. (2007). Phylogenetic and physiological studies of four hydrogen-producing thermoanaerobes from Icelandic geothermal areas. Icelandic Agric Sci 20, 93-105.

Skirnisdottir, S., Hreggvidsson, G. O., Hjöleifsdottir, S., Marteinsson, V. T., Petursdottir, S. K., Holst, O. \& Kristjansson, J. K. (2000). Influence of sulfide and temperature on species composition and community structure of hot spring microbial mats. Appl Environ Microbiol 66, 2835-2841.

Smibert, R. M. \& Krieg, N. R. (1994). Phenotypic characterization. In Methods for General and Molecular Bacteriology, pp. 607-654. Edited by P. Gerhardt, R. G. E. Murray, W. A. Wood \& N. R. Krieg. Washington, DC: American Society for Microbiology.

Stackebrandt, E. \& Goebel, B. M. (1994). Taxonomic note: a place for DNA-DNA reassociation and 16S rRNA sequence analysis in the present species definition in bacteriology. Int J Syst Bacteriol 44, 846849.

Stöhr, R., Waberski, A., Liesack, W., Völker, H., Wehmeyer, U. \& Thomm, M. (2001). Hydrogenophilus hirschii sp. nov., a novel thermophilic hydrogen-oxidizing $\beta$-proteobacterium isolated from Yellowstone National Park. Int J Syst Evol Microbiol 51, 481-488.

Thompson, J. D., Gibson, T. J., Plewniak, F., Jeanmougin, F. \& Higgins, D. G. (1997). The CLUSTAL_X windows interface: flexible strategies for multiple sequence alignment aided by quality analysis tools. Nucleic Acids Res 25, 4876-4882.

Van de Peer, Y. \& De Wachter, R. (1997). Construction of evolutionary distance trees with TREECON for Windows: accounting for variation in nucleotide substitution rate among sites. Comput Appl Biosci 13, 227-230. 